\section{Reinventing government}

The September report of Vice-President Gore's National Performance Review, "From Red Tape to Results: Creating a Government That Works Better \& Costs Less," described hundreds of actions and recommendations designed to cut red tape and produce better government for less cost. Information technology and electronic government were emphasized. Details are gradually becoming known, and supplementary reports are expected. This column highlights two areas of recommendations that would have a profound effect on library services and on public access to government information.

\section{Library program eliminations}

The report recommends elimination or consolidation of more than 40 Department of Education programs and freeing up resulting savings for use in other educational programs. The report cites the HEA Act II-C research library program as an example of a program that has served its original purpose, and says university endowments should be used to build library collections. In fact, the II-C program is designed to help major research libraries make their resources more accessible to users outside their own primary clientele-an appropriate federal role. The administration was poised, as this column was written, to submit a request to Congress to rescind or defund all FY94 funds just appropriated for a number of ED programs. The six library programs on the rescission list include, in addition to LSCA public library construction and library literacy programs, all currently funded HEA II programs (see table).

The administration is highlighting libraries as a key element in its "National Information Infrastructure: Agenda for Action" (see Pat Wand's article in this issue). However, the National

\begin{tabular}{|c|c|c|c|}
\hline \multicolumn{4}{|c|}{ HIGHER EDUCATION ACT } \\
\hline (amounts in thousands) & $\begin{array}{l}\text { FY } 1993 \\
\text { APPROPS. }\end{array}$ & $\begin{array}{r}\text { FY } 1994 \\
\text { HOUSE }\end{array}$ & $\begin{array}{l}\text { FY } 1994 \\
\text { SENATE }\end{array}$ \\
\hline $\begin{array}{l}\text { II-A, College Library Technology } \\
\text { and Cooperation Grants }\end{array}$ & $\$ 3,873$ & $\$ 3,873$ & $\$ 3,873$ \\
\hline $\begin{array}{l}\text { II-B, Library Education and } \\
\text { Human Resource Development } \\
\text { II-B, Library Research and }\end{array}$ & 4,960 & 4,960 & 4,960 \\
\hline Demonstrations & 2,802 & 2,802 & 2,802 \\
\hline $\begin{array}{l}\text { II-C, Improving Access to } \\
\text { Research Library Resources }\end{array}$ & 5,808 & 5,808 & 5,808 \\
\hline
\end{tabular}

Performance Review would eliminate most programs targeted to assist libraries to use electronic technologies and networks to develop, access, and share resources. The requested library program eliminations, proposed earlier in Clinton's FY94 budget, have already been rejected by Congress. These proposals are not a new "reinventing government" idea, but a resurrection of previous administrations unsuccessful attempts to eliminate libraries from Department of Education priorities. The ACRL Legislative Network was among the groups being called to action.

\section{Government printing \& depository library program}

The report's recommendation to "Eliminate the Government Printing Office's Monopoly" is a continuation of a long-standing controversy over government printing policy. Implementation would require Congress to amend Title 44 printing requirements, and ignores the fact that the GPO already contracts out most executivebranch printing. Following a recommendation to assure public access to federal information, the report states: "Give the executive branch agencies responsibility for distributing printed federal information to depository libraries. Require agencies to inventory the federal information they hold, and make it accessible to the public." After seeing a draft of the "reinventing support services" section, ALA

(Cont. on page 591) 


\section{HOW DO I SEARCH THEE? LET ME COUNT THE WAYS...}

\section{Search by poet (we have the works of more than 1,300 ) \\ Search by place of publication \\ Search on bibliographic information (more than 4,500 volumes represented) \\ Search by words in the title \\ Search for words close together}

\begin{tabular}{|c|}
\hline 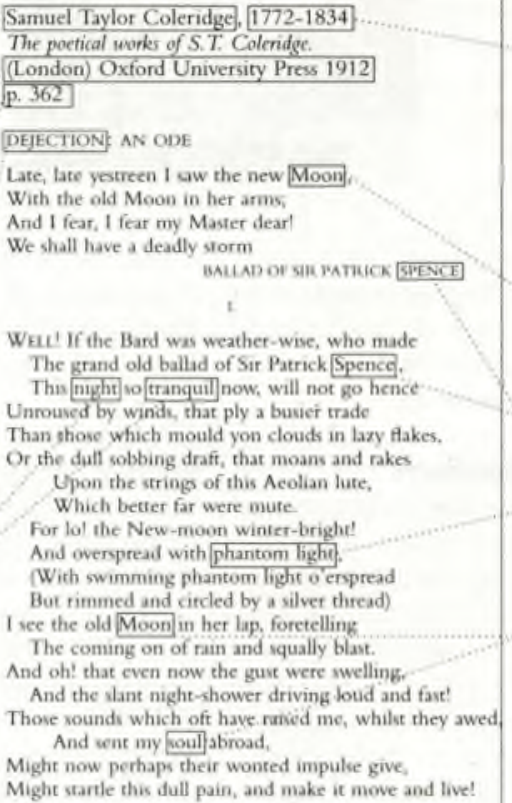 \\
\hline
\end{tabular}

Search in seconds...electronically.

Search the largest and most accessible full-text database yet published in the humanities.

Search Chadwyck-Healey's The English Poetry Full-Text Database on CD-ROM and magnetic tape.

Call today and learn how your library can offer electronic access to the world's largest collection of fully encoded English poetic literature - and let the search for knowledge begin.

CHADWYCK-HEALEY INC.

\section{Search by poet's dates (from the Anglo-Saxon period to the late nineteenth century)}

\section{Search for words in epigraphs}

Search for words throughout the database

\section{Search for} phrases

\section{Search for any} two words in a poem

1101 King Street Suite 380

Alexandria, VA 22314

Toll-free in the U.S. and Canada (800) 752-0515

Fax (703) 683-7589 
Training Program. The awards will support a year of full-time study for seven doctoral students and six master's degree students. Recruiting for the master's fellowships will emphasize three specialty areas cataloging, systems analysis, and children's services. The professional school currently offers two master's degrees, a post-master's certificate of advanced study, and a doctoral degree in information and library science.

\section{The University of West Florida Library,}

Pensacola, has received a $\$ 9,976$ grant from the Florida State Historical Records Advisory Board to compile and publish a new comprehensive guide to Special Collections and West Florida Archives.

\section{Virginia Commonwealth University librar-}

ies, Richmond, have been awarded a grant from the National Historical Publications and Records Commission to process the manuscript collection of a prominent Virginia suffragist. The $\$ 30,720$ grant will fund a full-time, one-year position to process the Adele Goodman Clark papers. Items in need of preservation treatment will be identified and a guide to the collection will be produced.

\section{The Wayne State University Library Sys-} tem, Detroit, has been awarded a $\$ 90,000$ grant from the U.S. Department of Education to add records of manuscript collections and oral history holdings of the Walter P. Reuther Archives of Labor and Urban Affairs into the OCLC database. The archives contain one of the most important archival collections in the United States on the history of the North American labor movement. The Reuther Archives and Wayne State University Library System are partners in this venture and will share staffing and expertise to complete the project.

\section{Acquisitions}

A collection of more than 8,500 books, 1,100 periodicals, personal papers, and other materials has been acquired by Abilene Christian University Library, Texas, from the family of Dr. LeMoine Gaunce Lewis, a biblical studies professor at the university from 1949 to 1985. An omnivorous reader and collector, Lewis spe- cialized in early church history. His collection includes materials written in a variety of languages, among them German, French, Hebrew, and Latin.

The papers and professional library of John Eliot Allen, professor emeritus of geology and author of more than 240 monographs and articles, have been acquired by the Branford Price Millar Library at Portland State University. Allen's library consists of over 900 pieces, including books, serials, pamphlets, and maps. Among the papers are geologic field manuals, typescripts of Allen's articles and books, and his professional and personal correspondence.

\section{The book collection of John Beaufont, for} many years the international drama and film critic for the Christian Science Monitor has been acquired by Teikyo Post University's Traurig Library and Learning Resources Center in Waterbury, Connecticut. The collection, consisting of approximately 1,900 volumes of drama and literature, was donated by Beaufort's widow, Francesca Bruning.

\section{An extensive collection of literary and}

historical first editions in English and American literature has been acquired by the University of Delaware Library. An especially rare item is the Audubon edition, The Birds of America from Original Drawings, published in 1860. It has chromolithography by Julius Bien and contains 105 double elephant plates depicting 150 species of birds. Only 49 copies of the volume are known to exist. The gift was given by $C$. Porter Shutt of Montchanin, Delaware.

\section{(Washington cont. from page 565)}

President Hardy Franklin wrote to Vice-President Gore to tell him of ALA's concerns about the printing recommendations. Franklin said the radical restructuring of the Depository Library Program called for requires evaluation and thorough examination before going forward, and pointed out that the proposed decentralization would result in increased costs and less efficiency for all participants: "There would be neither a single point of access to publications for depository libraries, nor a single mechanism for administering the Depository Library Program."

Carol C. Henderson is deputy executive director of ALA's Wasbington Office; bitnet: ccb@alawash.org 